\title{
Commodity Market Prices and Its Impact on Exchange Rate of Pakistan
}

\author{
ASAD SARFARAZ KHAN \\ PhD Scholar, Abasyn University Peshawar, Pakistan \\ Asad_as2002@awkum.edu.pk \\ DR. SHAKIL IQBAL AWAN \\ Assistant Professor, Iqra University Islamabad Campus, Pakistan \\ siqbal@iqraisb.edu.pk \\ DR. SYED ABDUL MOIZ \\ Dean, Faculty of Economics \\ Kardan University, Kabul, Afghanistan \\ a.moiz@kardan.edu.af
}

\begin{abstract}
Pakistan's economy and exchange rate has experienced many ups and downs in the last ten years. The exchange rate has depreciated from Rs.59/\$ to Rs.104/\$. This is causing a massive dent to Pakistan economy. According to the State Bank of Pakistan, Pakistan is consistently facing a current account deficit for the last several years and a depreciated currency is one of the main reasons for the deficit. This study analyzes the relationship between the commodity market prices and exchange rates in Pakistan both in long and in short run. This research utilized the monthly data for the past ten years from Jan-2006 to Dec-2015. The results are quite surprising because in Pakistan, none of the prices of the commodities (i-e oil and gold) have short term relationship with the exchange rate of Pakistan. This study also does not find any long-term relationship among the variables.
\end{abstract}

Keywords: Exchange rate, Oil prices, Gold Prices, Co-integration, Granger causality.

\section{Introduction}

After its independence in 1947, Pakistan was a poor country and its economy was based on agriculture. Then slowly industrial growth started and in 1960 Pakistan became a model of economic growth worldwide and around the world Karachi appeared to be an economic model. Since 1951 recession, Pakistan's GDP has grown every year. But now its economy is considered as unstable and vulnerable to the internal/external events that happened in the last decade or so such as, economic sanctions by the US and war on terror etc which severally deteriorated its economical growth. The Pakistani currency was pegged to the US dollar till 1982 (Moffat, 2010). But then President Zia Ul Haq government changed it to managed float. It is since then when the Pakistani currency started to depreciate. The year 2008 has been seen as the most devastating year for its currency and now in 2016 the rupee has recorded its ever-lowest rate against US dollar. As a result, the cost of importing raw material is increasing rapidly and causing a huge pressure on its balance of payment. A country whether developed or developing, its currency holds a big stake in its economy. Valuable currency helps in producing a good 
economic condition; it helps the countries to perform well in the trade. Pakistani economy is an oil dependent economy rather it is an import-oriented economy and the fluctuations in the prices of internationally traded commodities can create many problems for its currency.

The sharp fluctuations of the oil prices have a very significant impact on the wealth of the nations. Golub (1983) has seen very closely the rise in the oil prices and has seen it as a transfer of wealth from oil importing countries to oil exporting countries. Pakistan is more like an import-oriented country and we can say that it is semiindustrialized economy, which mainly consists of textile, chemical, agriculture, and other small industries. For an import-oriented country like Pakistan, the prices of international commodities such as Oil and Gold play an important role in its balance of payments and currency exchange rate. According to Chao, Chen, Hu, Huang and Wang in 2014, the stock prices and foreign reserves of a country is increased because of its depreciated currency. The reason behind this is that when a domestic currency is devaluated, the current account balance is increased and that of a capital account is decreased so that equilibrium in a foreign exchange market is maintained. Therefore the interest rate in domestic country is decreased. Besides this the depreciated currency also increase net exports and increase domestic prices. Decrease in the interest rate and an increase in the domestic prices both increases the foreign reserves if the monetary market is in equilibrium state.

As per information on the economic condition of Pakistan in financial year 2008, the Pakistani currency has lost worth due to political and financial instability. At present, the Pakistan' s economy is passing through the political and economic turmoil. Following Mumbai incident, Pakistan faced huge economic crisis because of the pressure from international community. In 2009, the country's largest stock exchange that is Karachi Stock Exchange witnessed a worst day as the index was dropped by five percent.. This has been documented as worst single-day act in last 32-month. Pakistan's economy and exchange rate has seen many ups and downs in the last ten years. The exchange rate has depreciated from Rs.56/\$ to Rs.91/\$. This is causing a massive dent to our economy. According to the state bank of Pakistan, Pakistan is consistently facing a current account deficit for the last five years (SBP, 2010). The fluctuations in the prices of the internationally traded commodities can be one of the main reasons for this deficit. Oil and Gold represent a significant fraction of the trade of a country and in a small economy like Pakistan, that has a floating exchange rate, the fluctuation in the prices of these commodities can have a great impact on its exchange rate. A depreciated currency is increasing our current account deficit that is why it is very important to know the reasons behind the consistent devaluation of our currency

This research work aims to examine the impact of fluctuations in Oil prices and Gold prices on exchange rate of Pakistan. To the best of our understanding, there is no study which has investigated the relationships between Oil rates, Gold rates and Pakistan's currency exchange rate. In Pakistan, it would help the economic analyst to relate the Oil prices, Gold prices and exchange rate and would help them in forecasting the economic growth more precisely. 


\section{Literature Review}

Exchange rate is the key element for the successful growth and survival of an economy. Regular fluctuation in exchange rate can severally damage any country's economy. Many researchers have conducted their researches in order to find out the reasons behind the variations in the currency exchange rate.The impact of the fluctuations in the prices of commodities in the international markets such as oil and gold on currency exchange rate has gained the attention of many researchers. Dooley, Isard and Taylor in 1995 identified that the fluctuations in the Gold prices appeared to have an instructive and explanatory power in the currency exchange rate movements, over and above the impact of fluctuations in monetary fundamentals and other variables that come into standard exchange rate model (Dooley, Isard \&Taylor, 1995). Sjaastad and Scacciavillani (1996) looked within the framework of law of one price at the impact of fluctuations of some major currencies on the prices of some internationally traded commodities. Their study argued the fluctuation in any major currency exchange rate that is involved in the trade of commodities that are commonly traded in an organized international market would have an immediate impact on the prices of those commodities to be adjusted accordingly. They decided to go for the gold as their commodity and took the international prices of gold because they were well aware of the fact that gold was such a homogeneous commodity that was regularly traded in well organized spot and future markets. Their findings showed that the international prices of gold are strongly affected by the fluctuations in the real exchange rate between Europe and U.S/Japan blocks of states (Sjaastad \& Scacciavillani, 1996).

Han, Xu and Wang (2008) investigated the fluctuations of exchange rates between US dollar Australian dollar, which are two key currencies in the foreign exchange market and the Gold prices were chosen as the core factor in determining the AUS/USD nominal spot rate. Gold prices were selected because Australia is the main exporter of the Gold. The Gold prices fluctuations appeared to be very crucial in valuation of the AUS \$. They reported a positive long run association between Gold prices and the exchange rate of AUS/USD. The increase in the Gold prices increased the Australia's revenue from Gold export in the long run which has strengthened the Australian economy which lead to tighter monetary policy and resulted in appreciation of Australian dollar. Lucey and baur in 2010 in their study found that both in normal market situations and distressed market situations, Gold is seen as a hedge against the fluctuations in U.S dollar on average (Baur, Lucey, 2010). A US based study investigated the gold prices and the US dollar and how this relationship is influenced by the current disorder in financial markets and their results suggested that the gold produce stable comovements with dollar and this has continued throughout the current stage of market distraction. They also found that exogenous instability shocks tend to create responses of the international prices that are more steady and constant to those of the U.S Dollar (Marzo \& Zagaglia, 2008).

Spero and Hart (1997) in their research study claimed that the rising inflation rate and the depreciation of the dollar lesser the real value of income from Oil production and therefore led OPEC countries to demand a sizeable increase in the price of Oil. Akram (2004) conducted an important study in Norway which is oil exporting country revealed a negative non-linear association between the Krone which is Norwegian currency and the prices of Oil. A change in the International prices of Oil appeared to have a sturdy 
impact on the Norwegian currency when the international prices of Oil are generally low. This study also found out that when the Oil prices are higher than the impact of Oil prices have a negligible effect on exchange rate.

One interesting study investigated the impact of US dollar on the OPEC's Oil prices and developed a correlation between the US dollar and Oil prices (Mothana, 2006). This study found that the devaluation of the US dollar has created problems for the world Oil industry. The research indicated that consumers in countries with non dollar appreciation currencies pay fewer prices for Oil such as euro and yen whereas dollar pegged countries pay higher prices for the same barrels of Oil. The relation of the currency exchange rate and the international prices of Oil are obvious. This connection of the Oil prices and currency exchange rate is being studied in Turkey, which is non-Oil producing country. By using the Johansen co integration and Granger causality tests, this study found out that the international Oil prices appeared to be granger causing the exchange rate of Turkey YTL and United States Dollar (Ozturk, Feridun \& Kalyoncu, 2008). Some economies are greatly vulnerable to Oil prices such as Russia where a research was carried out to see the connection between the Oil prices volatility and exchange rate and real GDP. The results of the study found that a $1 \%$ increase or decrease in Oil prices caused $.17 \%$ of appreciation or depreciation in the exchange rate and declined .46\% GDP in the long run (Lto, 2010). Empirical evidence on the impact of the fluctuations in the prices of internationally traded commodities such as oil and gold on exchange rate is mixed and ambiguous. For instance, Ozturk, Feridun and Kalyoun (2008) found that the fluctuations in the crude oil prices have granger caused the USD/YTL exchange rate. Similarly, Han, Xu and Wang (2008) took another important commodity Gold and found that the gold prices have very positive long run impact on exchange rate. On the other hand, Akram (2004) examined the impact of international oil prices on exchange rate in Norway and found that if the change in the oil prices is higher than the impact on exchange rate is negligible. The theory is equally ambiguous on the direction of the correlation between the exchange rate fluctuations and commodity prices. For instance, Cooper (1994) found that it is the exchange rate that influences the oil prices instead of the other way around. This study tried to attempt to further clarify this relationship in Pakistan.

\section{Methodology}

Monthly observations for the last ten years are used in this research study which covers a period from Jan 2006 to Dec 2015. Data on oil prices and Gold prices came from U.S energy information administration and world gold council respectively and that for exchange rate of Pakistan came from State bank of Pakistan. Once the data was gathered, it was tested for normality and for this purpose descriptive statistics was used to see the normality of the data. Then the variables are checked for both short term relationship and long term relationship. 


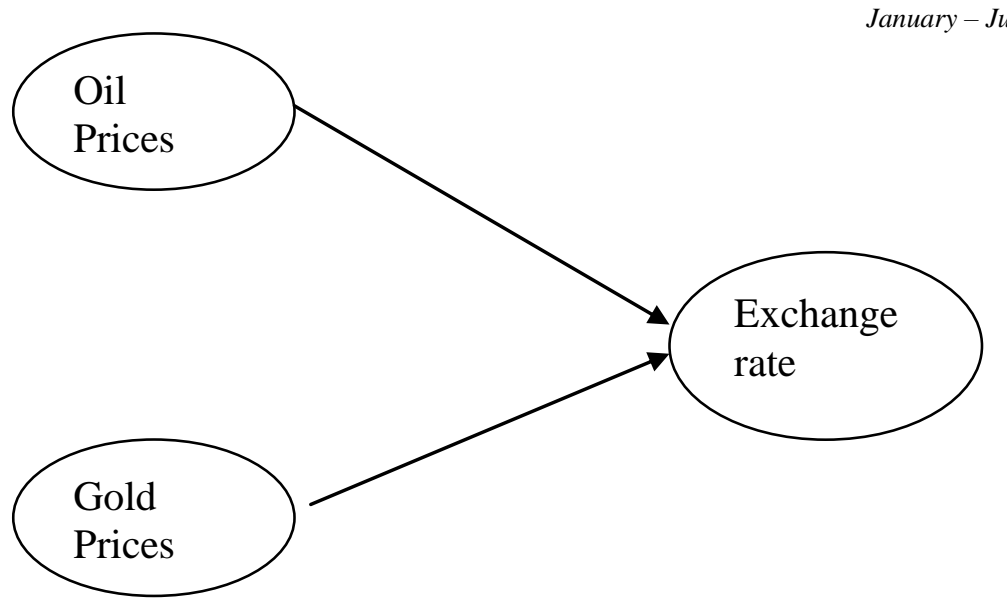

Graphical model of the research

The first step in performing any short term test on the secondary data is to see the stationarity of the time series data. Unit root test was applied to see the stationarity of the time series data. Phillips- Perron (PP), Dickey-fuller (DF) and Augmented Dickey-fuller are the three available tests to see if there is a unit root in the series or not. To see whether the time series are stationary or not, this research study employed Augmented Dickey Fuller test ADF (1981). Log values are used for unit root and co-integration. However, for the purpose of causality, logarithmic returns of the series are used in order to make the econometric testing measures more valid. ADF is preferred because in DF we don't have the concept of lag values and ADF incorporate up to second difference.

After the series become stationary, the study in order to examine the short run relationship between Gold prices, Oil prices and Exchange rate of Pakistan employed Granger Causality test. Granger explanation of causality is the most broadly used theory of causality. According to Granger in 1969, A is assumed to "Granger cause" B if B is better forecasted by the previous values of $\mathrm{A}$. In short, if $\mathrm{A}$ can facilitate to predict $\mathrm{B}$, then we can state that A Granger Cause B. If A causes B and B does not Granger Causes A then unidirectional causality is present from A to B. If A does not Granger Causes B and $\mathrm{B}$ does not cause $\mathrm{A}$ then $\mathrm{B}$ and $\mathrm{A}$ are statistically independent. The next step is to observe the long run association amongst the variables and for this purpose; this research study employed co- integration analysis to find out the long run association among the variables. Johansen and Juselius recommended Johansen co-integration test in 1990.

\section{Results and Discussions}

In this section, results derived from Augmented Dickey Fuller test, Granger Causality test and co-integration test are presented and discussed in detail.

Table 1. Results of Augmented Dickey-Fuller tests 


\begin{tabular}{lccc} 
Journal of Business and Tourism & & $\begin{array}{c}\text { Volume 03 Number 01 } \\
\text { January - June, 2017 }\end{array}$ \\
\hline & & $1 \%$ level & -3.486064 \\
ADF test statistics - OP & -7.529019 & $5 \%$ level & -2.885863 \\
& & $10 \%$ level & -2.579818 \\
ADF test statistics - GP & -9.735537 & $1 \%$ level & -3.486064 \\
& & $5 \%$ level & -2.885863 \\
& & $10 \%$ level & -2.579818 \\
ADF test statistics - ER & -7.080438 & $1 \%$ level & -3.486064 \\
& & $5 \%$ level & -2.885863 \\
\hline
\end{tabular}

Most of the time series are encountered to be non-stationary. A series is said to be stationary if it's mean and auto covariance do not depend on time. Non-stationarity can lead to spurious regression. The non-stationarity of the series can strongly influence its behavior and properties. For instance, if two variables are trending over time, a regression of one on the other can have a high " $R$ square" even if the two are totally unrelated.

Table 1 shows the results of Augmented Dickey Fuller tests of all the variables to test the stationary status of the data. As it is cleared from the above table that t-statistics of OP which is Oil prices is (-7.529019) which is greater than its critical value ($2.885863)$ at $5 \%$ of significance level. The t-statistics of Gold prices which is (9.735537) is greater than its critical value $(-2.885863)$ at $5 \%$ level of significance and the $\mathrm{t}$-statistic of exchange rate is $(-7.080438)$ which is also greater than its critical value ($2.885863)$ at $5 \%$ level of significance. The Augmented Dickey Fuller tests show that all the variables including that are Oil prices, Gold prices and Exchange rate are stationary at returns and are now ready to be used for short term test that is Granger Causality.

Table 2 . Results of Granger Causality tests

\begin{tabular}{cccc}
\hline Null hypothesis & Observations & F-statistics & Prob.** \\
\hline ROP does not Granger causes RER & 118 & 1.98476 & 0.1422 \\
RER does not Granger causes ROP & & 3.00897 & 0.0533 \\
RGP does not Granger causes RER & \multirow{2}{*}{118} & 0.00708 & 0.0326 \\
RER does not Granger causes RGP & & 3.52766 & 0.9929
\end{tabular}

*Sig at 0.05 level

Granger (1969) approached to the question of whether x causes y. To see how much of the current y can be explained by $x$. Here, the granger causality is used to see how much variation in exchange rate can be explained by oil prices and gold prices. Table 2 shows the results of Granger Causality tests between the dependent variables ROP and RGP that are the returns of oil prices and gold prices and independent variable RER; this is the returns of exchange rate. The results find no Granger Causality between ROP and RER because the f-statistics for ROP (1.98476) is less than 2 and its probability is greater than .05. The results do find no granger causing between RER and RER and there is no granger causality between RGP and RER at 5\%,. The results of the granger causality tests in the above table indicate that oil prices and gold prices do not explain exchange rate.

In other words, none of the commodity prices appeared to be affecting the exchange rate of Pakistan. An important need in the econometrics is the need to integrate the short-term dynamics with long run. The analysis of short run dynamics is often done by eliminating the trends in the series. This procedure throws the potential information. 
Therefore, to incorporate this information the variables are tested for co integration, which shows the long run relationship among the variables (Engle and Granger, 1987).

Table 3 . Johansen's cointegration test for oil prices and exchange rate Unrestricted Cointegration Rank Test (Trace)

\begin{tabular}{ccccc}
\hline $\begin{array}{c}\text { Hypothesized } \\
\text { No. of CE(s) }\end{array}$ & Eigen value & Trace statistics & $\begin{array}{c}0.05 \text { critical } \\
\text { value }\end{array}$ & Prob.** \\
\hline None & 0.063577 & 10.66769 & 15.49471 & 0.2328 \\
At most 1 & 0.024413 & 2.916500 & 3.841466 & 0.0877 \\
\hline
\end{tabular}

*sig at 0.05 level

Table 4 . Unrestricted Cointegration Rank Test (Maximum Eigen value)

\begin{tabular}{ccccc}
\hline $\begin{array}{c}\text { Hypothesized } \\
\text { No. of CE(s) }\end{array}$ & Eigen value & $\begin{array}{c}\text { Max-eigen } \\
\text { statistics }\end{array}$ & $\begin{array}{c}0.05 \text { critical } \\
\text { value }\end{array}$ & Prob.** \\
\hline None & 0.063577 & 7.751186 & 14.26460 & 0.2328 \\
At most 1 & 0.024413 & 2.916500 & 3.841466 & 0.0877 \\
\hline
\end{tabular}

*sig at 0.05 level

Table 3 and 4 indicate the results of the Johansen's co-integration tests for oil prices and exchange rate. The results indicate that there is no co-integration between oil prices and exchange rate. The trace statistics (10.66769) is less than its critical value (15.49471) at 5\% level of significance with probability also greater than .05 and the eigen value $(0.063577)$ is also less than its max-eigen statistics (7.751186) with probability greater than .05 which indicates that there is no cointegration between oil prices and exchange rate of Pakistan.

Table 5. Johansen's cointegration test for gold prices and exchange rate Unrestricted Cointegration Rank Test (Trace)

\begin{tabular}{ccccc}
\hline $\begin{array}{c}\text { Hypothesized } \\
\text { No. of CE(s) }\end{array}$ & Eigen value & Trace statistics & $\begin{array}{c}0.05 \text { critical } \\
\text { value }\end{array}$ & Prob.** \\
\hline None & 0.048518 & 8.209433 & 15.49471 & 0.4433 \\
At most 1 & 0.019642 & 2.340784 & 3.841466 & 0.1260 \\
\hline
\end{tabular}

*sig at 0.05 level

Table 6. : Unrestricted Cointegration Rank Test (Maximum Eigen value)

\begin{tabular}{ccccc}
\hline $\begin{array}{c}\text { Hypothesized } \\
\text { No. of CE(s) }\end{array}$ & Eigen value & $\begin{array}{c}\text { Max-eigen } \\
\text { statistics }\end{array}$ & $\begin{array}{c}0.05 \text { critical } \\
\text { value }\end{array}$ & Prob.** \\
\hline None & 0.063577 & 5.868650 & 14.26460 & 0.6301 \\
At most 1 & 0.024413 & 2.340784 & 3.841466 & 0.1260 \\
\hline
\end{tabular}

*sig at 0.05 level

Table 5 and 6 indicate the results of the Johansen's co-integration tests for gold prices and exchange rate. The results indicate that there is no co-integration between gold prices and exchange rate. The trace statistics (8.209433) is less than its critical value (15.49471) at $5 \%$ level of significance with probability also greater than .05 and the eigen value $(0.063577)$ is also less than its max-eigen statistics (5.868650) with probability greater than .05 which indicates that there is no cointegration between gold prices and exchange rate of Pakistan.

\section{Conclusion, Limitations and Future directions}

Pakistan's economy and exchange rate has seen many difficulties in the last ten years. The exchange rate has depreciated from Rs.59/\$ to Rs.104/\$. This is causing a massive dent to the economy of the country. This research utilized the monthly data for 
the past ten years to identify the reasons behind this depreciation of the currency. Monthly data is preferred from daily or yearly because the fluctuations in the monthly data are more visible compare to the daily data. Extensive past literature suggest that the fluctuations in the international prices of commodities such as oil and gold in the international market affect the currency exchange rate.

The study employed the Granger Causality test for the short term relationship and Johansen co-integration test for the long term relationship. The study found no Causal relationship of the international prices of Oil with the exchange rate of Pakistan, which is inconsistent with Ozturk, Feridun and Kalyonku (2008), who found Causal relationship between Oil prices and exchange rate in Turkey.

This study also found no Causal relationship between international Gold prices and exchange rate of Pakistan, which is also inconsistent with the literature as Dooley, Isard and Taylor (1995) who found that the Gold prices movements have instructive power with respect to exchange rate movements. The results of this research study also found no con-integration between oil prices and exchange rate, which is also inconsistent with Amano, Simon and Norden (1998) who found co-integration between oil prices and exchange rate. This empirical analysis concluded that there is no impact of oil and gold prices on the value of Pakistani currency both in the long run and in the short run at 5\% level of significance. The constant devaluation of the currency could be the consequences of some other events in Pakistan like political instability, law and order situation and corruption, the payments made for these commodities and the illegal transfer of millions of US dollars to other countries from Pakistan unofficially. These types of activities are also one of the main reasons of continuous depreciation of our currency. This study used past ten years data and only two commodities are tested against exchange rate of Pakistan. The future research should include more commodities like steel, cotton and other internationally traded commodities and should also use data for more than past ten years in order to have a more detail on this study and reach to a conclusion.

\section{References}

Akram, F. Q. (2004). Oil prices and exchange rates: Norwegian evidence. Econometric journal, 7(2), 476-504.

Amano, R. A., \& Norden, S. V. (1998). Exchange rate and oil prices. Review of international economics, 6(4), 683-694.

Baur, D. G., \& Lucey, B. M. (2010). Is Gold a Hedge or a Safe Haven? An Analysis of Stocks, Bonds and Gold. The Financial Review, 5(3), 217-229.

Chao, C.C., Chen, L.J., Hu, S.W., Huang, C.Y. \& Wang, V. (2014). Stock prices, foreign reserves and regime collapse. Asia-Pacific journal of accounting and economics, 21(2), 207-225.

Cooper, R. (1994). Changes in exchange rates an oil prices for Saudi Arabia and other OPEC members. The journal of energy and development, 20(1), 109-128.

Dooley, M. P., Isard, P., \& Taylor, M. P. (1995). Exchange rates, country specific shocks and gold rates. Applied financial economics, 5(1), 121-129.

Engle,R.F., \& Granger,C.W.J. (1987). Co-Integration and error correction: Representation, Estimation and testing, Econometrica, 55(2), 251-276.

Golub, S. S. (1983). Oil prices and exchange rates. Economic journal, 93(4), 576-593. 
Han, A., Xu, S., \& Wang, S. (2008). Australian dollar exchange rate and gold prices: An interval method analysis. ISORA, 08, 46-52.

Lto, K. (2010). The impact of oil volatility on macroeconomic activity in Russia. Documentos de Trabajo en Analisis economic, 9, 5.

Marzo, M., \& Zagaglia, P. (2008). Gold and the US dollar: Tales from the Turmoil. The Rimini center for economic analysis.

Moffat, M. (2010). Money and monetary economics, retrieved from http://economics.about.com/cs/money/a/gold_standard.htm on Dec. 05, 2010.

Mothana, O. S. (2006). Do oil prices depend on the value of US dollar? Ekonomicky casopis, 54(3), 253-265.

Ozturk, I., Feridun, M.m \& Kalyoncu, H. (2008). Do oil prices affect the USD/YTL exchange rate: Evidence from Turkey. Privrenda kretanja ekonomska politika, 118(115), 48-61.

Sjaalad, L., \& Scacciavitlani, F. (1996). The price of gold and the exchange rates. Journal of international money and finance, 15(6), 879-897.

Spero, J. E., \& Hart, J. A. (1997). Oil, Commodity Cartels, and power. Routledge: St. Martin's press.

State Bank of Pakistan (2016). Monthly statistical bulletin, annual report of state bank of Pakistan.

World Gold Council (2016). Historical gold price. retrieved from http://www.gold.org/statistics\#group1 on March 13.

U.S. Energy Informaion Administration (2016). Peteroleum and other liquids. Retrieved http://tonto.eia.gov/dnav/pet/hist/LeafHandler.ashx?n=PET\&s=RBRTE\&f=M 